\title{
Research on the development model of rural three-dimensional e-commerce
}

\author{
Xiaoyu Zou ${ }^{1, \text { a }}$ \\ ${ }^{1}$ School of Yantai University, Yantai 264000, China \\ a505772196@qq.com
}

Keywords: Rural area; E-commerce; three-dimensional development model.

\begin{abstract}
In the process of traditional agricultural transformation, upgrading and structural adjustment, the rural e-commerce which arise at the historical moment is an opportunity to accelerate agricultural modernization. Therefore, it will achieve the effect of yielding twice the result with half the effort to find a forward-looking rural e-commerce development model with universal applicability. In this paper, it puts forward a rural "three-dimensional" e-commerce development model which is one overall coordinated by the government, which mobilizes the enthusiasm for development in the four fields of agriculture, production, study and research, as well as gold, and ultimately achieves comprehensiveness, informationization and modernization. This model emphasizes on bringing the positive role of the multiple bodies in rural electronic commerce, and the purpose of which is to build a rural e-commerce industry system and accelerate the promotion and application of electronic commerce in rural areas.
\end{abstract}

\section{Introduction}

For rural electronic commerce, because of its convenience, high efficiency, low cost and that it can break the barriers of time and space, and other characteristics, it has made a qualitative leap in transaction efficiency, amount and scope, so it has important significance for realizing the rural modernization of our country and accelerating the construction of new countryside.

However, the development of rural electronic commerce is facing many realistic problems, it is influenced by society, technology, economy and many other aspects. Therefore, We need to solve problems that exist in rural electronic commerce by according to the law of e-commerce development, and thus putting forward the countermeasures and suggestions that are functioned overall and three-dimensional by government, agriculture, production, study and research, and gold.

The rural "three-dimensional" e-commerce development model refers to a comprehensive coordinated rural e-commerce development model that is guided by the government, and plans the four areas of agriculture, government, production, study and research, and which is supplemented by financial institutions. Among the four areas, "agriculture" refers to rural areas, farmers and agricultural products; "government" refers to the guidance and organizational work in the policy aspect conducted by the government to rural electronic commerce; "production" refers to technological innovation used to realize agricultural industrialization, deepen industrial chains and promote industries; and the last one "study and research" refers to talent cultivation and technical offering by schools and research units.

\section{Development model of "three-dimensional" e-commerce in rural areas}

\subsection{The government helps farmers to establish modern business ideas}

It is an important link to realize agricultural modernization to let farmers step into the information society, get involved in the big tide of electronic commerce, and become the beneficiary of e-commerce model, and it is also a great chance for modern science and technology, as well as modern concepts to change the destiny of farmers. But in the case of farmers' understanding of the importance of electronic commerce is universally insufficient, governments should attach importance 
to improve farmers' awareness of electronic commerce, and they need to carry out widely publicity and encouragement.

(i). Guiding farmers to understand electronic commerce. Governments need to help farmers to improve their understanding of electronic commerce, and they need to make great efforts to do it by taking it as an important strategic task for realizing rural urbanization and agricultural modernization. Governments at the county and urban levels need to transmit the strategic briefing on developing electronic commerce to the lower levels in the form of documents, and pilot to carry out some preferential policies, so as to encourage farmers to participate in electronic commerce. For township governments, by taking each village as the unit, they need to popularize farmers' comprehensive and correct understanding of electronic commerce, strengthen their recognition of rural electronic commerce, and deepen their edge belief in electronic commerce.

(ii). Training farmers' market management awareness. In order to realize the modernization of agriculture, we must change the farmers' thinking way of traditional small-scale peasant economy, and have an integrated market awareness. For farmers, they need to be fully aware that agricultural and sideline products are products of the integrated market, the demand and supply of which is regulated by the market. In order to improve farmers' understanding of development electronic commerce, governments at the township level can become the direct promoter for electronic commerce, they can summarize experience and publicize and guide farmers by typical and key successful ones. Meanwhile, governments need to teach the relevant marketing knowledge to farmers, especially publicizing for young farmers and farmer cadres.

\subsection{Setting up a scientific talent cultivation system}

The development of rural electronic commerce requires talents. Currently, although it is universally believed by villagers and cadres at the township government level that there is a lack of talents who are proficient in e-commerce information technology, this is actually a superficial phenomenon, and the deepen question is to develop e-commerce management talents, which more lacks in rural electronic commerce, including the collection and transmission of information, the allocation and transfer of products, etc. Therefore, governments need to start from the following several aspects:

(i). They need to train college-graduate village officials in a centralized manner. They need firstly to take the development of electronic commerce in rural areas as one of performance appraisals for college-graduate village officials, and encourage them to actively promote the e-commerce development of villages they are in. In order to encourage and support college-graduate village officials, governments can provide corresponding support policies for them, such as tax benefits, loans discounts and financial discounts. Governments provide free and considerate technical support and information services for their entrepreneurs. For those village officials who have made contributions and have outstanding achievements, governments can reward them or confer honors to them, etc..

(ii). College-graduate village officials open public training courses for villagers regularly. Counties (cities) need to set up a special rural e-commerce office, which provide specialized business training, and the main training object is college-graduate village officials and village cadres. The "leading" role or "effect of staying together" need to be stressed, and a pilot or typical one needs to be set up. Or with a group consisting of many people as the unit, each unit trains several leaders, and these leaders can therefore train other members.

(iii). Governments bear the following functions in this aspect: the first one is policies on talent cultivation, they need to increase the investment intensity of talent cultivation for developing electronic commerce in rural areas, and they need to encourage all types of vocational technical colleges to place their internship base in townships. The second one is the function of supervision and evaluation. They need to supervise and evaluate the performance of township cadres in developing electronic commerce.

The specific measures are involved in the following three aspects: first of all, providing opportunities of internship for college students by the alliance of governments, colleges and universities, so that colleges and universities can deliver talents for e-commerce construction in rural 
areas. Second, by running schools jointly with local education and training institutions, governments can oriented train professional talents, including technical and management talents. Third, placing governments and their performances open. Publicize the evaluation criteria and performances of township cadres in the process of developing rural electronic commerce, and accept the two-way supervision and evaluation of common people and provincial governments.

\subsection{Set up the agricultural products' own logistics system with the "three-dimensional function”}

This is to establish an own logistics system with three-dimensional functions of agriculture, production, study and research in the process of developing electronic commerce by according to the agricultural products have strong seasonal characteristics, the storage and transportation of them have timeliness and for the sake of avoiding the shortcomings caused by a third party logistics, so as to realize the integration of the production, transportation and sales of agricultural products. This is a key link for developing rural electronic commerce.

(i). Establish a joint association with county (city) - township as the unit by according to the regional characteristics of agricultural products, and take own logistics as a part of the association. In addition, own logistics can also be the content of the third industry in rural areas, the logistics facilities of which shall be improved by the rural areas and managed unified by the association. In this way, the construction and use of self-owned logistics not only can serve the local rural electronic commerce, which can also serve other industries, get a profit and become an industry of the local village as the third party logistics.

(ii). The funds sources of self-owned logistics can be divided into three parts, including governments' funds for supporting farmers, farmers' equity funds and the risk funds of markets. With self-owned logistics, farmers unified transport products from the producing place to the sales place, which not only can avoid the shortcomings of the third party logistics, it can also gain a good service reputation, ensuring the quality of agricultural products, building the local agricultural product reputation and increasing the sales amount of products.

(iii). Realizing the large-scale production of agricultural products is the condition to achieve self-owned logistics from the source, and it is also the requirement for farmers to really grasp the initiative of logistics. It can unit the strengths of local farmers together to jointly set up self-owned logistics, improve the discourse power of logistics by implementing land circulation policy and realizing the large-scale production and procedure in the production - processing -selling process of agricultural products, so as to change the disadvantages of the previous single farmers, and grasp the initiative of logistics fundamentally.

(v). We need to introduce modern science and technology into agriculture, introduce or establish processing enterprises of modern agricultural products. We can improve the added value of agricultural and sideline products by relying on the integration of agriculture, governments and production, we can also not lower prices by processing and avoiding products that are easy to store, so that they are free from seasonal extrusion, so as to thoroughly get rid of having damages on farmers because of the seasonal characteristics of agricultural products. By introducing preferential policies, governments can encourage individuals or enterprises to build a modern agricultural product processing production line, enrich the varieties of agricultural products, deepen the industrial chain of agricultural products, improve the added value of agricultural and sideline products, extend the shelf life of them, reduce additional cost brought by the storage of agricultural and sideline products, and enhance the confidence of farmers for markets and electronic commerce.

\subsection{Establish multiplex financing countermeasures}

It is found by investigation and research that the funds used for developing rural electronic commerce currently mainly rely on bank loans. Some farmers have no loan repaying capacities, and some hope that governments can make a difference in terms of financing. This idea actually originates from farmers' reliance on governments, and governments still need to lead farmers to step in markets in this aspect. For governments, they can make policies, and introduce risk funds into rural electronic commerce. 
(i). Establish a perfect rural credit system, which include the credit in agricultural banks, banks of merchants and other financial organizations. In order to enable farmers to have a faster loans speed and a conciser procedure, governments can communicate with the local banks to relax restrictions on farmers' loans. One one hand, appropriately lower the threshold on loan object. On the other hand, in terms of the interest rate of loans, we can reduce the repayment pressure of farmers in the form of governments' discounts in interest rates.

We need to set up merchant-peasant support funds and bear the main risks of farmers' loans by taking governments as the dominance. In order to reduce the risk of bad debts, and reduce the risk of paying the bill for bad debts by governments, departments related to governments can establish a set of standardized merchant-peasant project audit system.

(ii). The introduction of risk funds. We need to encourage risk funds to enter into rural electronic commerce, and risk funds mainly function on dominant e-commerce supply chain activities. For both governments and banks are not suitable for bearing additional risks in the credit process, so in addition to perfecting the credit system, we also need to make full use of the advantages of risk funds.

(iii). Bringing the function of the financial funds used for supporting farmers into play-. Governments can pay the bill for logistics, information flow, talent flow and other e-commerce infrastructure, the relevant environmental hardware, so farmers and consumers are the beneficiaries. For governments, they can set up merchant-peasant support funds and implement loan discount policy for farmers who apply for loans by allocating part funds from financial revenues.

\section{Conclusions}

By seeing from the angle of the current development situation of rural electronic commerce, especially starting from the standpoint of governments, this study puts forward practical and valuable feasibility suggestions for the development of electronic commerce in rural areas. It puts forward the rural "three-dimensional" e-commerce development model creatively, and the proposal of the model provides a feasible and specific development scheme for rural electronic commerce, which has more maneuverability and practical significance.

\section{References}

[1]Dell. Ivanic R,Akridge J,F Dooley. E-commerce Strategies among agricultural input firms. C Ehmke-StaffPaper, 2001[D].

[2]J Henderson,F Dooley,J Akridge. Internet and e-commerce adoption by agricultural input firms. Review of Agricultural Economics,2004.

[3]0. Folorunso, Sushil K. Sharma, H.O.D Longe,K. Lasaki. An Agent-based Model for Agriculture E-commerce System[J], Information Technology Journal.2006,5(2): 230-234.

[4]Nicole Leroux, Max S. Wortman, Eric D. Mathias. Dominant Factors Impacting the Development of Business-to-business (B2B) E-commerce in Agriculture[J], The International Food and Agribusiness Management Review. 2001,4(2):205-218.

[5]Janene Carey.Hutchinson Software.Potential Impact of e-commerce on Regional Australian Communities.

[6]Shivraj K.On the emancipatory role of rural information systems, Information Technology \& People[QK], 2004,17(4):407-422. 